Anais da Academia Brasileira de Ciências (2012) 84(1): 149-156

(Annals of the Brazilian Academy of Sciences)

Printed version ISSN 0001-3765 / Online version ISSN 1678-2690

www.scielo.br/aabc

\title{
Assessment of Duguetia furfuracea genotoxic and cytotoxic activity in bacteria and mice
}

\author{
CAROLINA R. SILVA ${ }^{1}$, PABLINE M. VIEIRA ${ }^{1}$, SUZANA C. SANTOS ${ }^{2}$ and LEE CHEN-CHEN ${ }^{1}$ \\ ${ }^{1}$ Departamento de Biologia Geral, Instituto de Ciências Biológicas, Universidade Federal de Goiás, \\ Caixa Postal 131, Campus-II, 74001-970 Goiânia, GO, Brasil \\ ${ }^{2}$ Instituto de Química, Universidade Federal de Goiás, Caixa Postal 131, Campus-II, 74001-970 Goiânia, GO, Brasil
}

Manuscript received on January 21, 2011; accepted for publication on June 6, 2011

\begin{abstract}
Duguetia furfuracea (St. Hil.) Benth \& Hook f. (1862), popularly known as "sofre-do-rim-quem-quer" and "araticum-seco", is a shrub of the Annonaceae family that occurs in several regions of Brazil. In folk medicine the infusion of its leaves and twigs is used to treat rheumatism and renal colic, whereas the seed powder is mixed with water to treat pediculosis. Previous studies have described biological activities of this plant with cytotoxic, antitumoral, trypanocidal, leishmanicidal, antiplasmodial and antiprotozoal effects. In the present work, genotoxicity and cytotoxicity of Duguetia furfuracea lyophilized leaf extract were evaluated using the prophage $\lambda$ induction test (SOS-Inductest) and mouse bone marrow micronucleus test. Our results showed that Duguetia furfuracea lyophilized leaf extract did not present an increase either in the induction of prophage $\lambda(\mathrm{P}>0.05)$ using the SOS-inductest or in the micronucleated polychromatic erythrocytes $(\mathrm{P}>0.05)$ using the micronucleus test, suggesting absence of genotoxicity in both tests. On the other hand, a significant decrease in the number of bacteria, $(\mathrm{P}<0.05)$, as well as a significant decrease in the polychromatic erythrocytes and normochromatic erythrocytes ratio, $(\mathrm{P}<0.05)$, were observed, showing the cytotoxic action of Duguetia furfuracea lyophilized leaf extract. Thus, Duguetia furfuracea did not present the genotoxic action, but showed a cytotoxic effect in both assays utilized in the present work.
\end{abstract}

Key words: cytotoxicity, Duguetia furfuracea, genotoxicity, micronucleus test, SOS-Inductest.

\section{INTRODUCTION}

In the last few decades, many health claims have been made for compounds derived from vegetables, fruits and plants (Veiga Junior et al. 2005). The active substances of the natural products are used as remedies for the treatment of many diseases (Pimenta and Nepomuceno 2005). A large number of plants have been screened as viable sources of a variety of

Correspondence to: Lee Chen-Chen

E-mail: chenleego@yahoo.com.br natural antioxidants, such as tocopherols, vitamin C, carotenoids, and phenolic compounds, which are responsible for human health maintenance, reduction of oxidative damage, and protection against coronary heart diseases and cancer (Kilani et al. 2008). Despite the increasing research on flora, only a small percentage of about 250,000 species of higher plants has been chemically and pharmacologically investigated (Ruffa et al. 2002), and data on the mutagenic properties of plants commonly used 
in folk medicine are limited (Ruiz et al. 1996). Green plants in general contain mutagenic and carcinogenic substances (Pimenta and Nepomuceno 2005, Sandermann Junior 1988, Velemi'nsky' and Gichner 1988, Kanaya et al. 1992, Plewa and Wagner 1993), but there is little information on the biological effects of the compounds present in these plant species (Pimenta and Nepomuceno 2005, Basaran et al. 1996). Therefore it is of vital importance to evaluate the genotoxic and cytotoxic effects of phytotherapeutic substances since their usage has major impacts on the health of a large number of people (Marques et al. 2003).

Duguetia furfuracea (D. furfuracea) (St. Hil.) Benth \& Hook f. (1862), popularly known as "sofredo-rim-quem-quer" and "araticum-seco", is a shrub of the Annonaceae family that occurs in several regions in Brazil (Carollo et al. 2006a, Rodrigues and Carvalho 2001). In folk medicine, the infusion of leaves and twigs of this species is used in the treatment of rheumatism and mainly in the treatment of renal colic (Rodrigues and Carvalho 2001). D. furfuracea seed powder is also used to treat pediculosis (SilberbauerGottsberger 1981/82). Alkaloids and flavonoids have already been isolated from the aerial parts of D. furfuracea and identified (Carollo et al. 2006a). Furthermore, many biological activities of this plant species were reported, such as toxicity in mice embryo (Toledo et al. 2006), trypanocidal, antiplasmodial, and antiprotozoal properties (Carollo et al. 2006a, Fischer et al. 2004, Mesquita et al. 2007).

Due to many biological activities presented by this plant, as well as to its widespread use in folk medicine by Brazilian people, the aim of this work was to assess the genotoxic and cytotoxic activities of D. furfuracea lyophilized leaf extract (DFE) using the lysogenic induction test (SOS-Inductest) (Moreau et al. 1976) and the mouse bone marrow micronucleus assay (Heddle 1973).

A combination of tests is generally applied to investigate the effect on the main types of DNA damage. The SOS-Inductest is a short term assay performed with Escherichia coli lysogenic strains allowing the quantitative evaluation of one SOS function. When bacteria are exposed to damaging DNA agents leading to the inhibition of DNA replication, this causes prophage to enter the lytic cycle as an expression of SOS induction (Moreau 1981).

The in vivo mouse bone marrow micronucleus test is a mutagenicity test system for the detection of agents that induce chromosome fragments (clastogenic effect) and/or aneuploidy (aneugenic effect) (Kirsch-Volders et al. 1997). Therefore, data obtained with both assays (one prokaryotic and other eukaryotic) in the present study represent a step further to the appropriate evaluation on the genotoxicity and cytotoxicity of $D$. furfuracea extract.

\section{MATERIALS AND METHODS}

PLANT MATERIAL

Samples of D. furfuracea leaves were collected in the district of Itanhangá, municipality of Goiânia, in the state of Goiás, Brazil. The plant was identified by Prof. Heleno Dias Ferreira, and a voucher specimen (no. 29975) was deposited in the Central Herbarium of the Universidade Federal de Goiás, in Goiânia, $\mathrm{GO}$, Brazil. The leaves of this plant were dried at $40{ }^{\circ} \mathrm{C}$ in a forced ventilation stove and ground in a fraction mill to a dry powder that was submitted to the hot aqueous extraction process $(85 \mathrm{~g} / 1000 \mathrm{~mL})$ and later to lyophilization. The lyophilized extract was stored at $-18^{\circ} \mathrm{C}$ until further use. Tests were done with the total lyophilized extract dissolved in water just before use.

\section{INDUCTEST}

\section{Strains}

The SOS-Inductest tester strains WP2s $(\lambda)$ (lysogenic strain) and RJF013 (indicator strain), derived from Escherichia coli, were kindly supplied by the Laboratório de Radiobiologia Molecular of 
the Instituto de Biofísica Carlos Chagas Filho, Universidade Federal do Rio de Janeiro, Rio de Janeiro, RJ, Brazil.

\section{SOS-Inductest - prophage $\lambda$ induction}

The experiments were performed according to Moreau et al. (1976). The lysogenic strain Escherichia coli WP2s $(\lambda)$, which contains a mutation in the gene uvrA (Fonseca et al. 1994), was cultured on LB medium ( $1 \%$ bacto tryptone, lot no. 9117660 , Difco, Sparks, USA; 0.5\% bacto yeast extract, lot no. 1551325, Biobras, Montes Claros, Brazil; 1\% NaCl, lot no. 87642, Vetec Química Fina Ltda, Duque de Caxias, Rio de Janeiro, Brazil) up to the exponential phase of growth. At this point, $15 \mathrm{~mL}$ of the culture were centrifuged at $3000 \times \mathrm{g}$ for $15 \mathrm{~min}$ and resuspended on an equal volume of M9 buffer $\left(0.6 \% \mathrm{Na}_{2} \mathrm{HPO}_{4}\right.$, lot no. 19117, Dinâmica Química Contemporânea, São Paulo, Brazil; 0.3\% $\mathrm{KH}_{2} \mathrm{PO}_{4}$, lot no. 1644, Cinética Química Ltda., São Paulo, Brazil; 0.5\% NaCl, lot no. 87642, Vetec Química Fina Ltda, Duque de Caxias, Rio de Janeiro, Brazil; $1 \mathrm{~mL} \mathrm{1M} \mathrm{MgSO}$, lot no. 871243, Vetec Química Fina Ltda, Duque de Caxias, Rio de Janeiro, Brazil). Following this, $1 \mathrm{~mL}$ aliquots of the bacterial culture were incubated with different doses of DFE $(1,2,5$ and $10 \mathrm{mg} / 0.1 \mathrm{~mL}$ - stocksolution $100 \mathrm{mg} / \mathrm{mL})$, the negative control $(100 \mu \mathrm{L}$ sterile distilled water), and the positive control [0.5 $\mu \mathrm{g}$ mitomycin $\mathrm{C}\left(\mathrm{C}_{15} \mathrm{H}_{18} \mathrm{~N}_{4} \mathrm{O}_{5}\right), \mathrm{MMC}$, lot no. 237AEL, Bristol, Mayers Squibb, São Paulo, Brazil], for $25 \mathrm{~min}$ at $37^{\circ} \mathrm{C}$, after what they were diluted in M9 buffer to undergo the assays. In order to assess the cytotoxicity of this plant, $0.1 \mathrm{~mL}$ of the dilutions in M9 buffer was inoculated into LB plates and incubated for $24 \mathrm{~h}$ at $37^{\circ} \mathrm{C}$. After this period, the total number of colonies was counted. To evaluate $D$. furfuracea genotoxicity, $0.1 \mathrm{~mL}$ lysogenic strain $E$. coli $\mathrm{WP} 2 \mathrm{~s}(\lambda)$ diluted in M9 buffer was added to $0.3 \mathrm{~mL} \mathrm{RJF013} \mathrm{culture}$ (indicator strain) and $2.5 \mathrm{~mL}$ top agar $(0.6 \%$ agar, lot no. 5294419, Difco, Sparks, USA; 0.5\% NaCl, lot no. 87642, Vetec, Duque de Caxias, Brazil). This mixture was poured into $\mathrm{LB}_{(1 / 2)(\text { malt/amp) }}$ plates and incubated for $24 \mathrm{~h}$ at $37^{\circ} \mathrm{C}$, after what the number of plaques was counted.

Mouse Bone Marrow Micronucleus Test

Animals

This study was approved by the Human and Animal Research Ethics Committee of the Universidade Federal de Goiás (CEPMHA/HC/UFG no. 044/09). Healthy, young male adult (8-12 weeks) outbred mice (Mus musculus, Swiss Webster), weighing 25$30 \mathrm{~g}$ and obtained from the Central Animal House of the Universidade Federal de Goiás were used in the study. All animals were brought to the laboratory five days before the experiments and housed in plastic cages $(40 \mathrm{~cm} \times 30 \mathrm{~cm} \times 16 \mathrm{~cm})$ at $24 \pm 2^{\circ} \mathrm{C}$ and $55 \pm 10 \%$ of humidity, with a light-dark natural cycle of $12 \mathrm{~h}$. Food (appropriate commercial rodent diet Labina, Ecibra Ltda., Santo Amaro, Brazil) and water were given ad libitum.

\section{Experimental procedure}

The experiments were performed according to Von Ledebur and Schmid (1973). Doses of DFE (100, 200, and $300 \mathrm{mg} / \mathrm{kg}$ body weight) were orally administered to groups of five animals for each treatment. A positive control group (4 mg/ kg i.p. MMC, lot no. 237AEL, Bristol, Mayers Squibb, São Paulo, Brazil) and a negative control group (sterile distilled water) were also included. The animals were euthanized 24 or $48 \mathrm{~h}$ after the administration of DFE by cervical dislocation, and their bone marrow cells were flushed from both femurs in fetal calf serum (FCS, lot no. 30721063, Laborclin, Campinas, Brazil). After centrifuging $(300 \times \mathrm{g}, 5 \mathrm{~min})$, the bone marrow cells were smeared on glass slides, coded for blind analysis, air-dried 
and fixed with absolute methanol $\left(\mathrm{CH}_{4} \mathrm{O}\right.$, lot no. 55026, Synth, Diadema, Brazil) for $5 \mathrm{~min}$ at room temperature. The smears were stained with Giemsa (lot no. 1081, Doles, Goiânia, Brazil), dibasic sodium phosphate $\left(\mathrm{Na}_{2} \mathrm{HPO}_{4} 12 \mathrm{H}_{2} \mathrm{O}\right.$, lot no. 982162 , Vetec, Duque de Caxias, Brazil) and monobasic sodium phosphate $\left(\mathrm{NaH}_{2} \mathrm{PO}_{4} \mathrm{H}_{2} \mathrm{O}\right.$, lot no. 983831, Vetec, Duque de Caxias, Brazil) to detect micronucleated polychromatic erythrocytes (MNPCE). For each animal, three slides were prepared and a minimum of 2,000 polychromatic erythrocytes (PCE) were counted to determine the frequency of MNPCE. In order to assess DFE cytotoxic activity, we determined the polychromatic erythrocytes (PCE) and normochromatic erythrocytes (NCE) ratio (PCE/ NCE). The slides were analyzed by microscopy (Olympus BH-2 $10 \times 100$, Tokyo, Japan).

\section{StATISTICAL ANALYSIS}

The results of the survival and genotoxicity assays by SOS inductest were generated by four independent experiments carried out in duplicates. All the data obtained from the test plates and the negative control plates (cytotoxicity assay), as well as the number of plaques obtained in the test plates and the number of plaques recorded in the negative control plates (genotoxicity assay) were expressed as mean $(\mathrm{m}) \pm$ standard deviation (sd). After this, they were evaluated using ANOVA tests and posthoc Tukey to compare the differences among the means (Vieira 2004), considering the results significant when $\mathrm{P}<0.05$.

In order to analyze the genotoxic activity of DFE using the mouse bone marrow micronucleus test, the frequencies of MNPCE of the treated groups were compared with the results obtained for the negative control groups using one-way ANOVA. $\mathrm{P}$ values lower than $0.05(\mathrm{P}<0.05)$ were considered indicative of significance. To assess its cytotoxicity, the PCE/NCE ratio obtained at different concentrations of DFE was compared with the negative controls by the qui-square test $\left(\chi^{2}\right)$. P values lower than $0.05(\mathrm{P}<0.05)$ were considered indicative of significance.

\section{RESULTS}

SOS-INDUCTEST

The results of DFE cytotoxicity and genotoxicity are presented in Table I.

Assessing the cytotoxicity of DFE, it was possible to observe a small increase in the number of survivors at the dose of $1 \mathrm{mg}$ compared with the negative control group, although not presenting a significant difference $(\mathrm{P}>0.05)$. At doses 2, 5, and $10 \mathrm{mg}$ of DFE, we detected a decrease in the number of survivors compared with the negative control, which showed a significant difference $(\mathrm{P}<0.05)$ only at the doses of 5 and $10 \mathrm{mg}$.

In the assessment of DFE genotoxicity, we noted that the dose of $1 \mathrm{mg}$ increased the induction of prophage $\lambda$ compared with the negative control group, but not presenting significant difference ( $\mathrm{P}>0.05$ ). Applying 2, 5 and $10 \mathrm{mg}$ of DFE, we observed a small decrease in the induction of prophage $\lambda$ compared with the negative control group, with no significant difference $(\mathrm{P}>0.05)$. The small induction observed at the $1 \mathrm{mg}$ dose of DFE may be related to the increased number of survivors at this dose (Table I).

Mouse Bone Marrow Micronucleus Test

MNPCE frequencies and PCE/NCE ratio at 24 and $48 \mathrm{~h}$ at different doses of DFE are shown in Table II.

The results for all tested doses (100, 200, and $300 \mathrm{mg} / \mathrm{kg}$ ) do not indicate any significant increase in MNPCE frequencies (both at 24 and 48 h) when compared with the negative control group $(\mathrm{P}>0.05)$, leading to the conclusion that DFE does not harbor a genotoxic effect. 
The PCE/NCE ratio can be an indicator of cytotoxicity. In this work, all tested doses (100, 200 , and $300 \mathrm{mg} / \mathrm{kg}$ ) at both times of treatment ( 24 and $48 \mathrm{~h}$ ) caused a significant reduction of $\mathrm{PCE} /$ NCE ratio compared with the negative control group at 24 and $48 \mathrm{~h}(\mathrm{P}<0.05)$. We observed that, $24 \mathrm{~h}$ after the treatment with $100 \mathrm{mg}$ of DFE, the reduction of $\mathrm{PCE} / \mathrm{NCE}$ ratio was small, although statistically significant $(\mathrm{P}<0.05)$, demonstrating moderate cytotoxicity of this plant extract.

\section{DISCUSSION}

The aim of this study was to evaluate the cytotoxic and genotoxic potential of DFE using the SOSInductest and mouse bone marrow micronucleus test. The SOS-Inductest identifies agents capable of producing DNA lesions, which block its replication and they detects the induction of the lytic cycle of prophage $\lambda$, which is one of the manifestations of SOS functions (Moreau et al. 1976). On the other hand, the bacterial survival assay is useful and necessary to define basal cytotoxicity, allowing the observation of the intrinsic ability of a compound to cause cellular death as a consequence of damage to basic cellular functions (Einsenbrand et al. 2002). The mouse bone marrow micronucleus test is a shortterm assay widely employed to detect the genotoxic (clastogenic and/or aneugenic) and cytotoxic effects of extracts of other plants (Vilar et al. 2008).

Non-significant increases in $\lambda$ prophage induction $(\mathrm{P}>0.05)$ in the SOS-Inductest or in MNPCE $(\mathrm{P}>0.05)$ in the micronucleus test were seen to occur, therefore suggesting that DFE lack genotoxic effect under the present testing conditions.

In contrast, we observed a significant decrease in the number of survivors at the doses of 5 and $10 \mathrm{mg}$ extract $(\mathrm{P}<0.05)$ by the SOS-Inductest, as well as a decrease in the PCE/NCE ratio using the mouse bone marrow micronucleus test, which shows the cytotoxic action of DFE. This finding is in accordance with the results already demonstrated for extracts made from this plant species in mouse embryos (Toledo et al. 2006).

It has been already known that cytotoxic agents can induce a great variety of events in the cell: DNA or protein damage, inhibition of growth, apoptosis, etc. The nature of the interaction between a drug and its target is of critical importance in determining the cell fate. Many cytotoxic drugs employed in chemotherapy, such as MMC and cyclophosphamide (CP), have their mechanism of action based on this genotoxic/mutagenic potential activity (Hickman et al. 1992, Estream and Vanleeuwen 2000, Kraut and Drnovsek-Olup 1996). However, the cytotoxic action presented in this work suggests that this activity did not result from genotoxic mechanisms. Possibly the toxic effects caused by exposition to DFE override any genotoxic and mutagenic effects. This fact suggests that DFE is not a procarcinogenic agent. Thus, this compound may cause degenerative pathways. Similar results were observed in the evaluation of the mutagenic and cytotoxic activities of ethanolic extracts of araticum (Annona crassiflora), which also had used the mice bone marrow micronucleus test (Vilar et al. 2008).

The phytochemical analysis of the aerial parts of D. furfuracea showed the presence of sesquiterpenes (Carollo et al. 2005), flavonoids, and several alkaloids (Carollo et al. 2006a, b). Moreover, recent studies demonstrated that the alkaloid extract and five alkaloids isolated from $D$. furfuracea subterranean stem bark presented cytotoxic, antitumoral, trypanocidal and leishmanicidal activites (Silva et al. 2009). Alkaloids have also been isolated from other species of the Duguetia genus and are common in the Annonaceae family (Leboeuf et al. 1980). It is widely known that alkaloids present cytotoxic activity and also potent topoisomerase II inhibition effect (Leboeuf et al. 1980, Woo et al. 1999, Pereira et al. 2003, Fechine et al. 2002, Maia et al. 2006, Muhammad et al. 2001, Tempone et al. 2005). Thus, the cytotoxic activity found in this study can be attributed, at least partially, to the action of alkaloids. 
TABLE I

Survival fraction (SF) and standard deviation (SD) of number of colonies of E. coli WP2s( $\lambda$ ), infective centers (IC) and standard deviation (SD) in RJF013 $E$. coli cultures formed after treatment with different doses of $D$. furfuracea

\begin{tabular}{c|c|c}
\hline Treatment & $\mathrm{SF} \pm \mathrm{SD}_{\text {(survival) }}$ & $\mathrm{IC} \pm \mathrm{SD}_{\text {(induction) }}$ \\
\hline Negative control $\left(\mathrm{H}_{2} \mathrm{O}\right)$ & $1.94 \times 10^{8} \pm 3.6 \times 10^{7}$ & $4.13 \times 10^{7} \pm 1.47 \times 10^{7}$ \\
$1 \mathrm{mg} \mathrm{DFE}$ & $2.1 \times 10^{8} \pm 2.5 \times 10^{7 \mathrm{~b}}$ & $9.7 \times 10^{7} \pm 4.3 \times 10^{7 \mathrm{~b}}$ \\
$2 \mathrm{mg}$ DFE & $1.6 \times 10^{8} \pm 6 \times 10^{7 \mathrm{~b}}$ & $3.48 \times 10^{7} \pm 1.39 \times 10^{7 \mathrm{~b}}$ \\
$5 \mathrm{mg}$ DFE & $1.02 \times 10^{8} \pm 1.2 \times 10^{7 \mathrm{a}}$ & $4.47 \times 10^{7} \pm 2.76 \times 10^{7 \mathrm{~b}}$ \\
$10 \mathrm{mg}$ DFE & $8.1 \times 10^{7} \pm 1.9 \times 10^{7 \mathrm{a}}$ & $2.09 \times 10^{7} \pm 5.8 \times 10^{6 \mathrm{~b}}$ \\
Positive control (MMC) & $2.18 \times 10^{6} \pm 1.67 \times 10^{6 \mathrm{a}}$ & $9.7 \times 10^{8} \pm 4 \times 10^{7 \mathrm{a}}$ \\
\hline
\end{tabular}

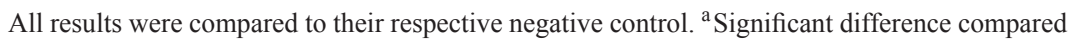
to the negative control $(\mathrm{P}<0.05)$. ${ }^{\mathrm{b}}$ No significant difference compared to the negative control (P>0.05). DFE, D. furfuracea lyophilized leaf extract; MMC, mitomycin C.

TABLE II

MNPCE frequencies and PCE/NCE ratio after treatment of the animals using different doses of Duguetia furfuracea lyophilized leaf extract and time.

\begin{tabular}{c|c|c|c|c|c}
\hline Treatment & Time (h) & $\begin{array}{c}\text { Individual data } \\
\text { (MNPCEs/2,000PCEs) }\end{array}$ & $\begin{array}{c}\text { Total Number } \\
\text { MNPCEs }\end{array}$ & $\begin{array}{c}\text { Mean } \pm \text { SD } \\
\text { (MNPCEs) }\end{array}$ & (PCEs/NCEs) \\
\hline Negative control (H2O) & 24 & $3,5,3,4,4$ & 19 & $3.8 \pm 0.74$ & $1.06 \pm 0.06$ \\
Positive control (MMC) & 24 & $29,40,36,38,35$ & 178 & $35.6 \pm 3.72^{\mathrm{a}}$ & $0.46 \pm 0.01^{\mathrm{a}}$ \\
Positive control (MMC) & 48 & $9,11,12,9,7$ & 48 & $9.6 \pm 1.74^{\mathrm{a}}$ & $0.26 \pm 0.006^{\mathrm{a}}$ \\
$100 \mathrm{mg} \cdot \mathrm{kg}^{-1}$ DFE & 24 & $5,5,7,7,6$ & 30 & $6 \pm 0.89^{\mathrm{b}}$ & $0.92 \pm 0.09^{\mathrm{a}}$ \\
$200 \mathrm{mg} \cdot \mathrm{kg}^{-1}$ DFE & 24 & $7,6,3,5,4$ & 25 & $5 \pm 1.41^{\mathrm{b}}$ & $0.83 \pm 0.02^{\mathrm{a}}$ \\
$300 \mathrm{mg} \cdot \mathrm{kg}^{-1}$ DFE & 24 & $7,5,7,3,6$ & 28 & $5.6 \pm 1.49^{\mathrm{b}}$ & $0.72 \pm 0.05^{\mathrm{a}}$ \\
$100 \mathrm{mg} \cdot \mathrm{kg}^{-1}$ DFE & 48 & $6,7,5,4,7$ & 29 & $5.8 \pm 1.16^{\mathrm{b}}$ & $0.83 \pm 0.1^{\mathrm{a}}$ \\
$200 \mathrm{mg} \cdot \mathrm{kg}^{-1}$ DFE & 48 & $3,6,5,4,4$ & 22 & $4.4 \pm 1.01^{\mathrm{b}}$ & $0.67 \pm 0.08^{\mathrm{a}}$ \\
$300 \mathrm{mg} \cdot \mathrm{kg}^{-1}$ DFE & 48 & $6,5,3,4,3$ & 21 & $4.2 \pm 1.16^{\mathrm{b}}$ & $0.72 \pm 0.07^{\mathrm{a}}$ \\
\hline
\end{tabular}

All results were compared to their respective negative control group. ${ }^{\text {a }}$ Significant difference compared to the negative control group $(\mathrm{P}<0.05) .{ }^{\mathrm{b}}$ No significant difference compared to the negative control group $(\mathrm{P}>0.05)$. MNPCE, micronucleated polychromatic erythrocyte; PCE, polychromatic erythrocyte; NCE, normochromatic erythrocyte; DFE, D. furfuracea lyophilized leaf extract; MMC, mitomycin C. 
In summary, D. furfuracea lyophilized leaf extract presented cytotoxic activity, but did not present genotoxic activity under the experimental conditions followed in this study.

\section{ACKNOWLEDGMENTS}

We are thankful to all the sponsors of this research project: Fundação de Amparo à Pesquisa do Estado de Goiás (FAPEG), Fundação de Apoio à Pesquisa (FUNAPE), Conselho Nacional de Desenvolvimento Científico e Tecnológico (CNPq), and Universidade Federal de Goiás (UFG).

\section{RESUMO}

Duguetia furfuracea (St. Hil.) Benth \& Hook f. (1862), popularmente conhecida como "sofre-dorim-quem-quer" e "araticum-seco", é um arbusto da família Annonaceae que ocorre em várias regiões do Brasil. Na medicina popular a infusão de suas folhas e galhos é usada no tratamento de reumatismo e cólica renal, enquanto que o pó da semente é misturado com água para o tratamento de pediculose. Estudos anteriores têm descrito atividades biológicas desta planta com ação citotóxica, antitumoral, tripanomicida, leishmanicida, antiplasmódica e antiprotozoárica. No presente trabalho, a genotoxicidade e citotoxicidade do extrato liofilizado de folhas de Duguetia furfuracea foram avaliadas pelo teste de indução profago $\lambda$ (Induteste-SOS) e pelo teste do micronúcleo em medula óssea de camundongos. Nossos resultados mostraram que o extrato liofilizado de folhas Duguetia furfuracea não apresentou um aumento na indução do profago $\lambda(\mathrm{P}>0,05)$ no Induteste-SOS e também não foi observado aumento do número de eritrócitos policromáticos micronucleados $(\mathrm{P}>0,05)$, no Teste do Micronúcleo, sugerindo ausência de genotoxicidade em ambos os testes. Por outro lado, uma diminuição significativa no número de bactérias, $(\mathrm{P}<0,05)$, bem como uma diminuição significativa na relação entre eritrócitos policromáticos e eritrócitos normocromáticos, $(\mathrm{P}<0,05)$, foram observadas, mostrando ação citotóxica do extrato liofilizado de folhas de Duguetia furfuracea. Assim, Duguetia furfuracea não apresentou ação genotóxica, mas mostrou um efeito citotóxico em ambos os testes utilizados no presente trabalho.

Palavras-chave: citotoxicidade, Duguetia

furfuracea, genotoxicidade, teste do micronúcleo, Induteste-SOS.

\section{REFERENCES}

Basaran AA, Yu TW, Plewa MJ ANd Anderson D. 1996. An investigation of some Turkish herbal medicines in Salmonella typhimurium and in the Comet assay in human lymphocytes. Teratog Carcinog Mutagen 16: $125-138$.

Carollo CA, Hellmann AR and IQueira JM. 2005. Sesquiterpenoids from the essential oil from leaves of Duguetia furfuraea (Annonaceae). Biochem Syst Ecol 33: 647-649.

CARollo CA, Hellmann-Carollo AR, Siqueira JM AND AlBUQUERQUE S. 2006a. Alkaloids and a flavonoid from aerial parts (leaves and twigs) of Duguetia furfuracea Annonaceae. J Chil Chem Soc 51: 837-841.

Carollo CA, Siqueira JM, Garcez WS, Diniz R AND FERNANDES NG. 2006b. N-nitrosoanonaine and N-nitrosoxylopine, aporphine alkaloids from Duguetia furfuracea. J Nat Prod 69: 1222-1224.

EINSENBRAND G ET AL. 2002. Methods of in vitro toxicology. Food Chem Toxicol 40: 193-236.

ESTREAM SA AND VANLEEUWEN RN. 2000. Use of mitomycin-C for maintaining myringotomy patency. Otolaryngol Head Neck Surg 122: 8-10.

Fechine IM, NaVArro VR, CUnha EVL, Silva MS, Maia JGS AND BARBOSA-FILHO JM. 2002. Alkaloids and volatile constituents from Duguetia flagellaris. Biochem Syst Ecol 30: 267-269.

FISCHER DCH ET AL. 2004. In vitro screening for antiplasmodial activity of isoquinoline alkaloids from Brazilian plant species. Acta Trop 92: 261-266.

Fonseca CAS, LeAL J, Costa SS ANd Leitão AC. 1994. Genotoxic and mutagenic effects of guarana (Paullinia cupana) in prokaryotic organisms. Mut Res 321: 165-173.

HEDDLE JA. 1973. A rapid in vivo test for chromosomal damage. Mutat Res 18: 187-190.

HiCKMAN JA, BeERE HM, WoOd AC, WATERS CM AND PARMAR R. 1992. Mechanisms of cytotoxicity caused by antitumour drugs. Toxicol Lett 64-65: 553-561. 
Kanaya N, TAKehisa S, NicolofF H, Nikolova T AND DAMIANOVA V. 1992. Plant extracts induce chromosome aberrations and sister-chromatid exchanges in Chinese hamster ovary cells and human lymphocytes. Mutat Res 281: 47-54.

KILANI S ET AL. 2008. In vitro evaluation of antibacterial, antioxidant, cytotoxic and apoptotic activities of the tubers infusion and extracts of Cyperus rotundus. Bioresour Technol 99: 9004-9008.

Kirsch-VOlders M, Elhajouji A, CUndari E AND VAN HUMMELEN P. 1997. The in vitro micronucleus test: a multi-endpoint assay to detect simultaneously mitotic delay, apoptosis, chromosome breakage, chromosome loss and non-disjunction. Mutat Res 392: 19-30.

KRAUT A AND DRNOVSEK-OluP B. 1996. Instillation of mytomicin c after recurrent pterygium surgery. Eur $\mathrm{J}$ Ophthalmol 6: 264-267.

Leboeuf M, Cavé A, Bhaumik PK, MukherJee B AND MUKHERJEe R. 1980. The phytochemistry of the Annonaceae. Phytochemistry 21: 2783-2813.

MAIA JGS, ANDRADE EHA, CARREIRA LMM AND OLIVEIRA J. 2006. Essential oil composition from Duguetia species (Annonaceae). J Essent Oil Res 18: 60-63.

Marques RCP, Medeiros SRB, Dias CS, Barbosafilho JM AND AGNEZ-Lima LF. 2003. Evaluation of the mutagenic potential of yangambin and of the hydroalcoholic extract of Ocotea duckei by the Ames test. Mutat Res 536: 117-120.

Mesquita ML, Grellier P, Mambu L, Paula JE AND ESPINDOLA LS. 2007. In vitro antiplasmodial activity of Brazilian Cerrado plants used as traditional remedies. J Ethnopharmacol 110: 165-170.

Moreau PL. 1981. Mécanismes de la mutagénèse et de l'induction lysogénique. Principe des tests bactériens pour la détection des cancérogènes et antitumoraux potentiels. Sci Techn Animaux Lab 6: 267-277.

Moreau PL, Bailone A And Devoret R. 1976. Prophage lambda induction in Escherichia coli K12 envA, uvrB: a highly sensitive test for potential carcinogens. Proc Natl Acad Sci USA 73: 3700-3704.

Muhammad I, Dunbar DC, TAKamatsu S, Walker LA AND CLARK AM. 2001. Antimalarial, cytotoxic, and antifungal alkaloids from Duguetia hadrantha. J Nat Prod 64: 559-562.

Pereira NFG, CARollo CA, Garcez WS and SiQueira JM. 2003. Novel santalane sesquiterpenoids from the stem bark of Duguetia glabriuscula - Annonaceae. Quim Nova 26: $512-516$.

Pimenta VMSD AND NePOMUCENO JC. 2005. Genotoxicity Testing of Plantago major Extracts in Somatic Cells of Drosophila melanogaster. Environ Mol Mutagen 45: 56-61.
PLEWA MJ AND WAGNER ED. 1993. Activation of promutagens by green plants. Annu Rev Genet 27: 93-113.

Rodrigues VEG AND CARVALHO DA. 2001. Levantamento etnobotânico de plantas medicinais no domínio do cerrado na região do Alto Rio Grande - Minas Gerais. Cienc agrotec 25: 102-123.

Ruffa mu, Ferraro G, Wagner mL, Calcagno ML, Campos RH and CaVallaro L. 2002. Cytotoxic effect of Argentine medicinal plant extracts on human hepatocellular carcinoma cell line. J Ethnopharmacol 79: 335-339.

Ruiz AR, DE LA Torre RA, Alonso N, Villaescusa A, BETANCOURT J AND VIZOSO A. 1996. Screening of medicinal plants for induction of somatic segregation activity in Aspergillus nidulans. J Ethnopharmacol 52: 123-127.

SANDERMANN JUNIOR H. 1988. Mutagenic activation of xenobiotics by plant enzymes. Mutat Res 197: 183-194.

Silberbauer-GotTSBERger I. 1981/82. O cerrado como potencial de plantas medicinais e tóxicas. Oréades 8: 15-30.

Silva DB, Tulli ECO, Militão GCG, Costa-Lotufo LV, Pessoa C, Moraes mo, Albuquerque S AND SIQUEIRA JM. 2009. The antitumoral, trypanocidal and antileishmanial activities of extract and alkaloids isolated from Duguetia furfuracea. Phytomedicine 16: 1059-1063.

Tempone AG, Borborema SET, De ANDrade JúNIOR HF, Gualda NCA, Yogi A, Carvalho CS, Bachiega D, Lupo FN, BonotTo SV AND FISCHER DCH. 2005. Antiprotozoal activity of Brazilian plant extracts from isoquinoline alkaloid-producing families. Phytomedicine 12: 382-390.

Toledo MRS ET AL. 2006. Fitotoxicidade do extrato aquoso de Duguetia furfuraceae (St. Hill) B et $\mathrm{H}$ em ratas (Rattus norvegicus). RBPM 8: 218-222.

Veiga Junior VF, Pinto AC AND Maciel MAM. 2005. Plantas Medicinais: cura segura? Quim Nova 28: 519-528.

VELEMI'NSKY' J AND GICHNER T. 1988. Mutagenic activity of promutagens in plants: indirect evidence of their activation. Mutat Res 197: 221-242.

VIEIRA SM. 2004. Bioestatística: tópicos avançados, 2nd ed., Rio de Janeiro: Campus, 216 p.

Vilar JB, Ferreira FL, Ferri PH, Guillo LA AND Chen CHEN L. 2008. Assessment of the mutagenic, antimutagenic and cytotoxic activities of ethanolic extract of araticum (Annona crassiflora Mart. 1841) by micronucleus test in mice. Braz J Biol 68: 141-147.

VON LEDEBUR MAND SCHMID W. 1973. The micronucleus test: methodological aspects. Mutat Res 19: 109-117.

Woo SH, Sun NJ, CASSAdy JM AND SnapKa RM. 1999. Topoisomerase II inhibition by aporphine alkaloids. Biochem Pharmacol 57: 1141-1145. 